\title{
Mangrove diversity along the coast of Ratnagiri, Maharashtra
}

\author{
Tarnnum Mubarak Mulla*, Niranjana Suneel Chavan
}

Department of Botany, Shivaji University, Kolhapur, Maharashtra, India

Received: 14.05 .2017

Accepted: 10.06 .2017

Published: 15.06.2017

*Address for correspondence: Tarnnum Mubarak Mulla, Department of Botany, Shivaji University,

Kolhapur - 416004 ,

Maharashtra, India.

E-mail: tmtanu@gmail.com

\begin{abstract}
The present paper deals with the study of mangrove diversity along different sites of Ratnagiri coast of Maharashtra, India. Height of the plants, importance value index (IVI) and various indices, namely, Simpson's index, Shannonweiner index, and Margalef index were determined. Maximum height was recorded from Chinchkhari site (8.76 meters). It was observed that the Sonneratia alba, Avicennia marina, and Ceriops tagal species showed the highest IVI from respective sites. Based on ecological indices, Narayanmali site was found to be rich in diversity while other sites are encroached and destructed mostly by anthropogenic activities. The piece of work is significant in comparing the diversity at the micro level by monitoring periodically for future programs.
\end{abstract}

KEY WORDS: Avicennia marina, importance value index, mangrove, Ratnagiri

\section{INTRODUCTION}

As a result of topography, substrate, latitude and hydrology, largely mangroves vary in their structure and function (Saenger and Snedaker, 1993). According to Cintron et al., 1978, Mitcsch et al., 2007 mangroves have been classified into four major associations. Separation is on the basis of structure, physical, climatic, and hydrologic features of the environment where the mangrove exist, i.e., fringe or coastal mangroves, riverine or estuarine mangroves, and basin mangroves, and dwarf scrub mangroves. In India, the east coast mangroves are deltaic, and the insular mangroves occur along the Andaman and Nicobar Islands (Oza and Zaidi, 2000, Venkataraman and Wafar, 2005). Funnelshaped estuaries or backwaters mangroves are found along the west coast of India (Gopal and Krishnmurthy, 1993). The diversity and composition of mangrove species varies site wise, zonation wise. Therefore, it is necessary to work out ecological parameters at the micro level. Assessment studies will be beneficial for monitoring the sites periodically. Thus, a present attempt has been made to study the diversity along various sites of Ratnagiri coast using various ecological indices.

\section{MATERIAL AND METHODS}

Five sampling sites were selected from Ratnagiri district (Plates 1-5). Observations were recorded from selected sites to study different ecological parameters. The diversity of mangroves was studied using biological indices such as Shannon-Weiner index (H) and Simpson's index (D) and Margalef index with the help of biodiversity Pro software. To study the composition of mangroves from different sites, the importance value index (IVI) was calculated. Quadrat method was followed $(10 \mathrm{~m} \times 10 \mathrm{~m})$ to calculate dominance, density, and frequency from five different sites.

\section{RESULTS AND DISCUSSION}

Geographical coordinates from the sampling sites were marked using global positioning system (Table 1). Total 11 typical mangrove species were recorded from five sites along Ratnagiri coast (Table 2). Acanthus ilicifolius, Ceriops tagal, Avicennia marina, Aegiceras corniculatum, and Sonneratia alba are common to all five sites while the occurrence of Rhizohora apiculata was noted in Chinchkhari, Narayanmali and Rajivada site. A. marina dwarf is restricted to Are and Sakhartar sites. The species composition differs at the micro level and site wise. Along the east coast of India, the total reported mangrove coverage is 58\%. In India the total coverage of mangrove is estimated to be $4740 \mathrm{~km}^{2}$ out of which $58 \%$ is along the east coast (Bay of Bengal), $29 \%$ along the west coast (Arabian Sea) and remaining $13 \%$ in the Andaman and Nicobar islands. (FSI, 2015). The average height for all the species was noted (Table 3 ). 


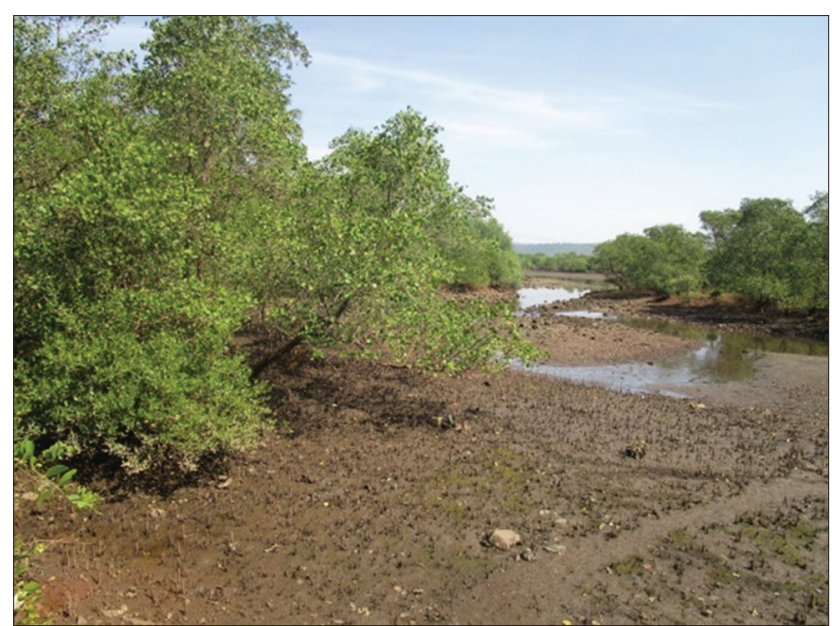

Plate 1: Are site

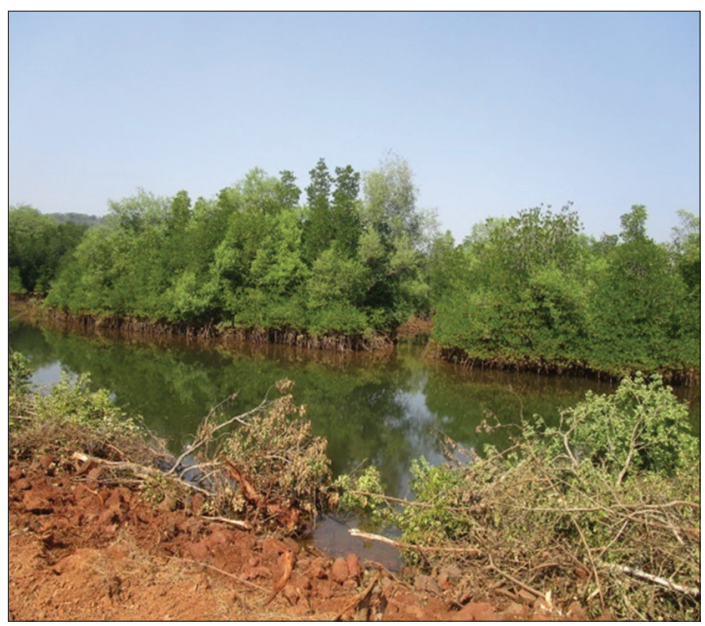

Plate 2: Chinchkhari site

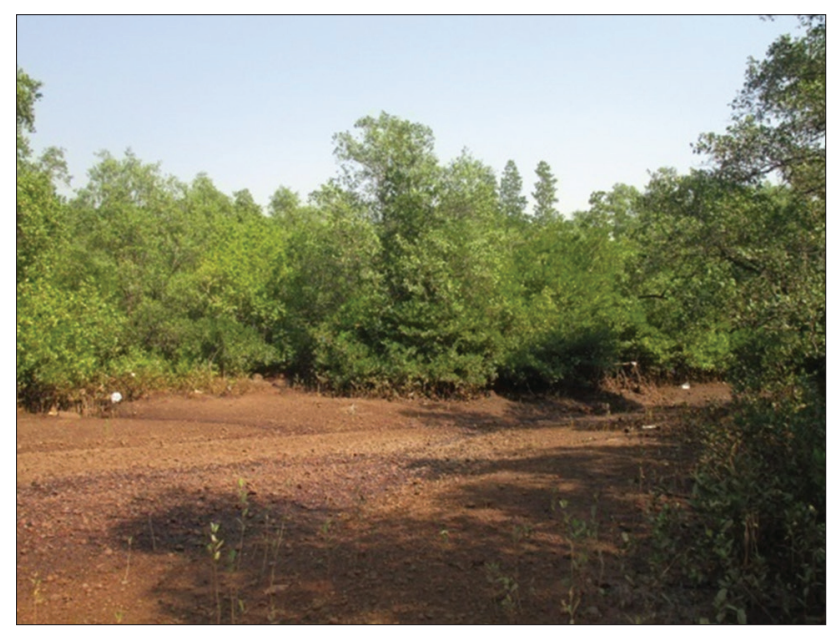

Plate 3: Narayanmali site

Avicennia officinalis from the site Chinchkhari shows the highest average height followed by Rajivada and Sakhartasr. In Rajivada site, A. marina shows the highest average height followed by the Narayanmali site. The same

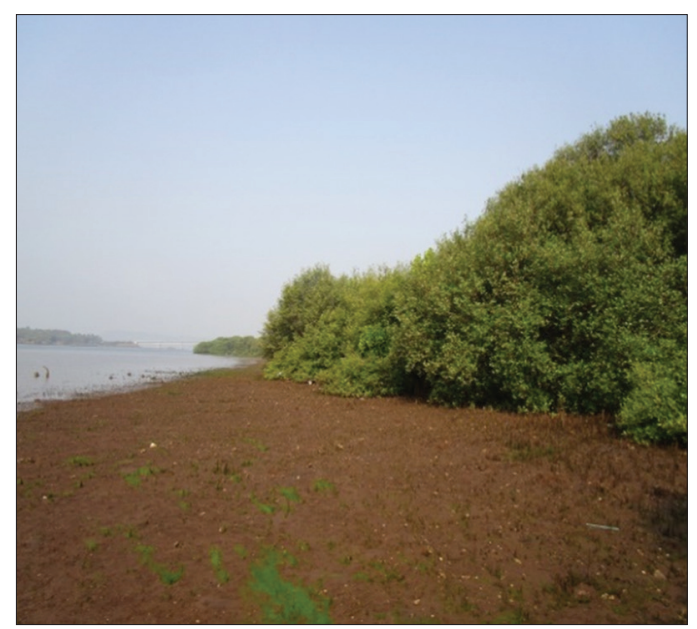

Plate 4: Rajivada site

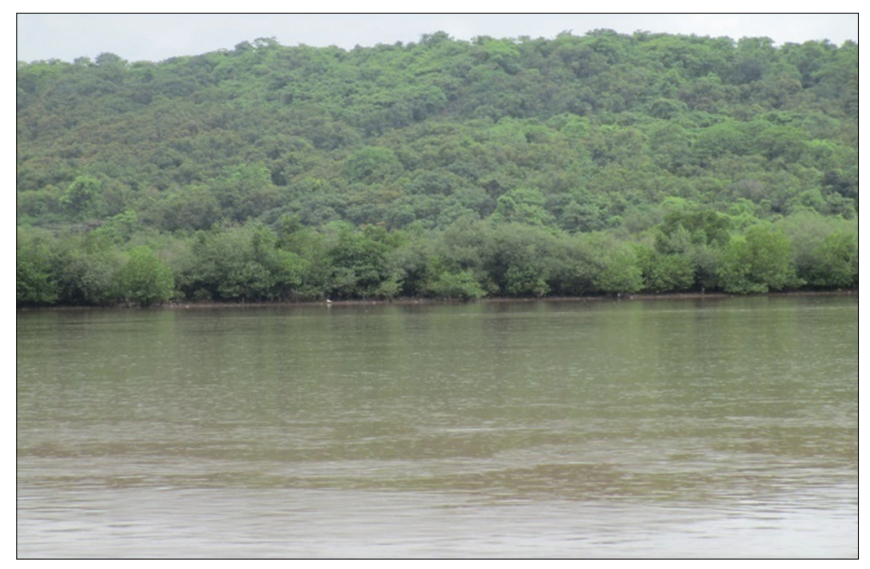

Plate 5: Sakhartar site

Table 1: Geographical coordinates of the sampling sites of Ratnagiri

\begin{tabular}{lcc}
\hline Name of sites & Longitude & Latitude \\
\hline Are & $17^{\circ} 04.370^{\prime} \mathrm{N}$ & $073^{\circ} 17.692^{\prime} \mathrm{E}$ \\
Chinchkhari & $17^{\circ} 01.614^{\prime} \mathrm{N}$ & $073^{\circ} 16.544^{\prime} \mathrm{E}$ \\
Narayanmali & $16^{\circ} 58.989^{\prime} \mathrm{N}$ & $073^{\circ} 18.046^{\prime} \mathrm{E}$ \\
Rajivada & $16^{\circ} 58.988^{\prime} \mathrm{N}$ & $073^{\circ} 18.047^{\prime} \mathrm{E}$ \\
Sakhartar & $17^{\circ} 04.372^{\prime} \mathrm{N}$ & $073^{\circ} 17.689^{\prime} \mathrm{E}$ \\
\hline
\end{tabular}

Table 2: List of typical mangrove species along the sites of Ratnagiri

\begin{tabular}{lll}
\hline Scientific name & Family & $\begin{array}{l}\text { Vernacular } \\
\text { name }\end{array}$ \\
\hline Rhizophora mucronata Lamk. & Rhizophoraceae & Kandal \\
Rhizophora apiculata Blume & Rhizophoraceae & Kandal \\
Ceriops tagal (Perr.) C.B. Rob. & Rhizophoraceae & Kirkiri \\
Avicennia marina (Forsk.) Vierh. & Avicenniaceae & Tivar \\
Avicennia marina (Dwarf) & Avicenniaceae & Tivar \\
Avicennia officinalis L. & Avicenniaceae & Tivar \\
Sonneratia alba J. Smith & Sonneratiaceae & Chipi \\
Aegiceras corniculatum (L.) Blanco. & Myrsinaceae & Sugandha \\
Lumnitzera racemosa Willd. & Combretaceae & - \\
Acanthus ilicifolius L. & Acanthaceae & Marandi \\
Excoecaria agallocha L. & Euphorbiaceae & Huri \\
\hline
\end{tabular}


study has been carried out in Bhavnagar, Surat, Navsari, and Bharuch sites of Gujarat where A. marina shows the maximum mean height, i.e., $127.28 \mathrm{~cm}$ at Navsari site and $114.6 \mathrm{~cm}$ at Bharuch site. Devi and Pathak (2016). Kathiresan et al., and Muniyandi (1986) have reported that Pichavaram mangrove forests of Tamil Nadu have trees with a low diameter $(3-18 \mathrm{~cm})$ and 4.8-5.9 $\mathrm{m}$ short canopies. Douglas et al., (1977) have made composition on Indian mangroves with Mexican species $(17 \mathrm{~m})$, Philippines (25-30 m) and South Sumatra (55 m). Figures 1-5 depicts the IVI. Highest value of index was noticed from Narayanmali site. S. alba shows highest important value index (187.53) followed by the C.tagal (124.72) and A. ilicifolius (118.29). Figure 1 indicates the dominance of S. alba species with IVI (174.33) followed by $A$. marina (131.11) and A. marina dwarf (122.07). Sakhartar site is dominated by the $S$. alba and A. marina patches with the IVI 134.5 and 152.38, respectively (Figure 5). The diversity indices of the five sites were performed and presented in Table 4. It is observed that the Margalef index was found to be higher in Narayanmali site (4.25). It has decreased to 2.82 for are site. The highest species richness was noted in the Narayanmali site compared to the other sites of Ratnagiri. The mean value of Simpson's

Table 3: Average height in meters and centimeters of mangroves along the sites of Ratnagiri

\begin{tabular}{|c|c|c|c|c|c|}
\hline \multirow[t]{2}{*}{ Name of species } & \multicolumn{5}{|c|}{ Name of sites } \\
\hline & Are & Chinchkhari & Narayanmali & Rajivada & Sakhartar \\
\hline $\begin{array}{l}\text { Rhizophora } \\
\text { mucronata }\end{array}$ & $2.74 \mathrm{~m}$ & $6.03 \mathrm{~m}$ & $3.17 \mathrm{~m}$ & $348 \mathrm{~m}$ & $2.82 \mathrm{~m}$ \\
\hline $\begin{array}{l}\text { Rhizohora } \\
\text { apiculata }\end{array}$ & - & $4.26 \mathrm{~m}$ & $3.64 \mathrm{~m}$ & $2.98 \mathrm{~m}$ & - \\
\hline Ceriops tagal & $2.41 \mathrm{~m}$ & $2.18 \mathrm{~m}$ & $2.46 \mathrm{~m}$ & $2.4 \mathrm{~m}$ & $1.86 \mathrm{~m}$ \\
\hline Avicennia marina & $4.26 \mathrm{~m}$ & $3.78 \mathrm{~m}$ & $5.30 \mathrm{~m}$ & $6.31 \mathrm{~m}$ & $4.63 \mathrm{~m}$ \\
\hline $\begin{array}{l}\text { Avicennia } \\
\text { officinalis }\end{array}$ & - & $8.76 \mathrm{~m}$ & $2.87 \mathrm{~m}$ & $4.93 \mathrm{~m}$ & $3.96 \mathrm{~m}$ \\
\hline Sonneratia alba & $4.85 \mathrm{~m}$ & $8.22 \mathrm{~m}$ & $4.38 \mathrm{~m}$ & $3.36 \mathrm{~m}$ & $5.16 \mathrm{~m}$ \\
\hline $\begin{array}{l}\text { Avicennia marina } \\
\text { dwarf }\end{array}$ & $100 \mathrm{~cm}$ & - & - & - & $82 \mathrm{~cm}$ \\
\hline $\begin{array}{l}\text { Aegiceras } \\
\text { corniculatum }\end{array}$ & $3.74 \mathrm{~m}$ & $2.7 \mathrm{~m}$ & $4.10 \mathrm{~m}$ & $1.56 \mathrm{~m}$ & $4.01 \mathrm{~m}$ \\
\hline $\begin{array}{l}\text { Lumnitzera } \\
\text { racemosa }\end{array}$ & $132 \mathrm{~cm}$ & - & - & $190 \mathrm{~cm}$ & $150 \mathrm{~cm}$ \\
\hline $\begin{array}{l}\text { Excoecaria } \\
\text { agallocha }\end{array}$ & $4.85 \mathrm{~m}$ & $3.91 \mathrm{~m}$ & $3.59 \mathrm{~m}$ & - & - \\
\hline $\begin{array}{l}\text { Acanthus } \\
\text { ilicifolius }\end{array}$ & $45 \mathrm{~cm}$ & $30 \mathrm{~cm}$ & $30.7 \mathrm{~cm}$ & $20.9 \mathrm{~cm}$ & $50 \mathrm{~cm}$ \\
\hline
\end{tabular}

Table 4: Diversity indices of the five sampling sites of Ratnagiri coast

\begin{tabular}{lccccc}
\hline Diversity indices & \multicolumn{5}{c}{ Name of sampling sites } \\
\cline { 2 - 6 } & Chinchkari & Are & Narayanmali & Sakhartar & Rajivada \\
\hline Shannon-Weiner & 0.813 & 0.649 & 0.842 & 0.822 & 0.810 \\
index & & & & & \\
Simpson's index & 0.147 & 0.219 & 0.132 & 0.148 & 0.149 \\
Margalef index & 3.60 & 2.981 & 4.25 & 3.63 & 3.12 \\
\hline
\end{tabular}

index was observed to be 0.219 at Are site shows the heterogeneity of the mangrove species. The diversity of species depends upon the adaptation which increases the stability of community (Singh et al., 1994). The mean value of Shannon-Weiner index ranges from the 0.649-0.842. The Narayanmali site has more diversity compared to the

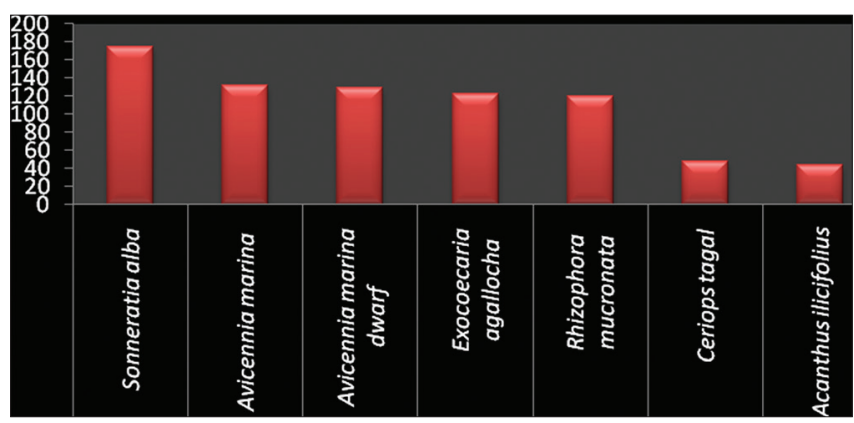

Figure 1: Importance value index of Are site

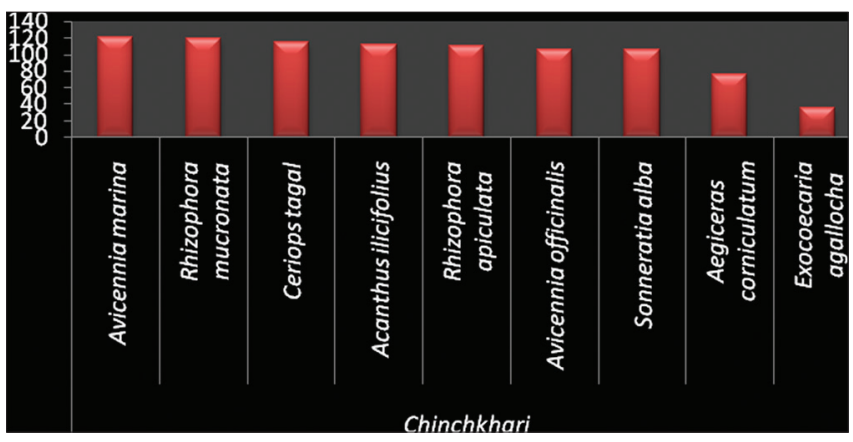

Figure 2: Importance value index of Chinchkhari site

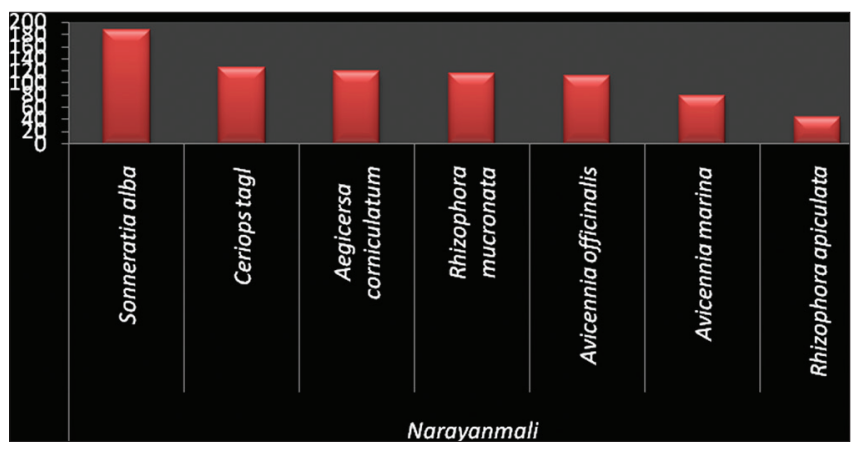

Figure 3: Importance value index of Narayanmali site

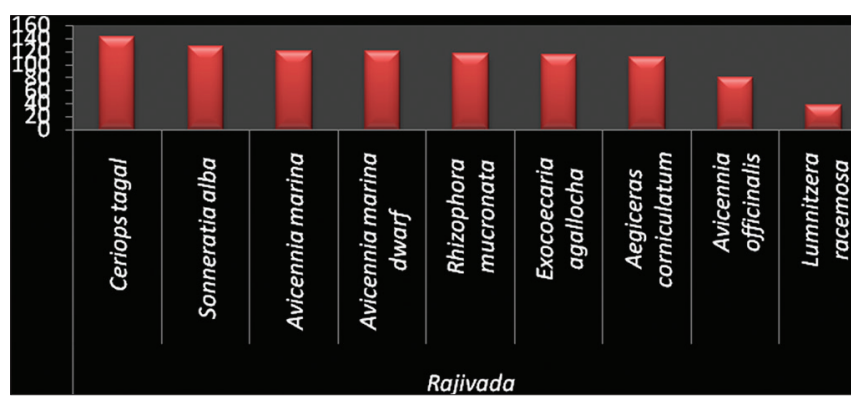

Figure 4: Importance value index of Rajivada 


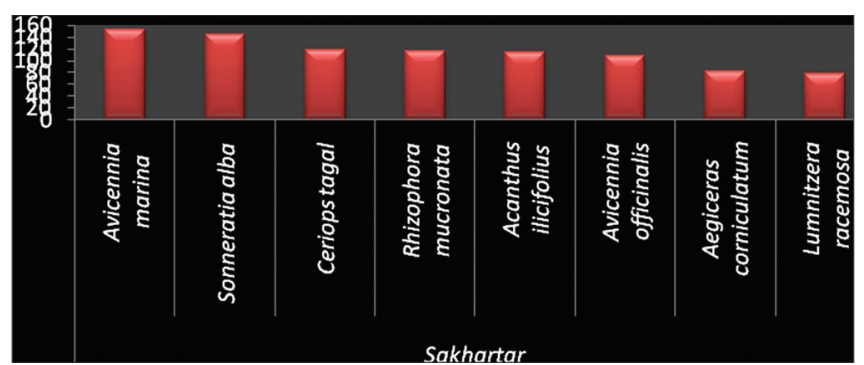

Figure 5: Importance value index of Sakhartar site

other sites. Similar attempts have been made by Volin et al., 2005 and Li et al., 2014. A. marina shows the higher density at Bhavnagar site where density of plant is more and mean height is less. This type of pattern has been observed and can be explained as there is reduction in growth of plants may be due to the competition for limited resources and destruction in mangrove habitat.

\section{CONCLUSIONS}

The study reveals that Narayanmali site is rich in diversity followed by Sakhartar. Based on the survey, it was observed that there is more than $50 \%$ destruction along Are, Chinchkhari, and Rajivada. The species such as R. apiculata are vanishing very fast along the sites of Ratnagiri. There is destruction of mangrove habitat by many anthropogenic activities such as felling of trees, encroachment for agriculture as well as construction of bunds. Therefore, based on the ecological studies it can be suggested that species such as Rhizophora, Sonneratia, and Avicennia may be conserved along the sites to save the coastal life as the major ecological function of these species is to protect the areas in and around the estuary.

\section{REFERENCES}

Cintron G, Lugo AE, Pool DJ, Morris G. Mangroves of arid environments in Puerto Rico and adjacent islands. Biottropica 1978;10:110-21.
Devi V, Pathak B. Ecological studies of mangrove species in Gulf of Khambhat, Gujarat. Trop Plant Res 2016;3:536-42.

Douglas JP, Snedaker SC, Ariel EL. Structure of Mangroves Forests in Florida. Puerto Rico: Mexico and Central America; 1977. p. 195-212.

FSI. India State of Forest Report. Dehradun: Forest Survey of India (FSI); 2015. p. 62-7.

Gopal B, Krishnamurthy K. Wetlands of south Asia. In: Whigam DF, Dykyjova D, Heinjy S, editors. Wetlands of The world I: Handbook of Vegetation Science Inventory, Ecology and Management. Dordrecht: Kluwer Academic Publishers; 1993. p. 345-414.

Kathiresan K, Ramesh MX, Venkatesan V. Forest structure and prawn seeds in Pichavaram mangroves. Environ Ecol 1994;12:465-8.

Li F, Xie Y, Tang Y, Chen X, Deng Z, Hu J, et al. Negative influence of burial stress on plant growth was ameliorated by increased plant density in polygonumhydropiper, limnologica. Ecol Manag Inland Waters 2014;45:33-7.

Mitcsch WJ, Gosselink JG. Wetlands. $4^{\text {th }}$ ed. New York, USA: John Wiley and Sons, Inc.; 2007. p. 582.

Muniyandi K. Studies on mangroves of Pichavaram (Southeast coast of India). Ph.D. Thesis, Annamalai University, Parangipettai, India; 1986. p. 15.

Oza RM, Zaidi SH. A Revised Checklist of Indian Marine Algae. Bhavnagar, India: Central Salt and Marine Chemical Research Institute; 2000. p. 296.

Saenger P, Snedaker SC. Pantropical trends in mangrove above-ground biomass and annual litterfall. Oecologia 1993;96:293-9.

Singh R, Thakur GC, Sood VK. Phytosociology and resource utilization by different forest trees in Southeastern slopes around Shimla, Himachal Pradesh Indian Forester 120; 1994. p. 1108-1117.

Venkataraman K, Wafar M. Coastal and marine biodiversity of India. Indian J Mar Sci 2005;34:57-75.

Volin HS, Novoplansky A, Goldberg DE, Turkington R. Density regulation in annual plant communities under variable resource levels. Oikos 2005;108:241-52. 